\title{
Digital Student Songbook as Supporting Thematic Teaching Material in Elementary School
}

\section{Desyandri' ${ }^{1}$ Indra Yeni' ${ }^{2}$, Mansurdin ${ }^{3}$, Alrizka Hairi Dilfa ${ }^{4}$}

1,2,3 Universitas Negeri Padang, Padang, Indonesia

${ }^{4}$ Universitas Negeri Semarang, Kota Semarang, Indonesia

\section{ART I CLE I N F O}

Article history:

Received March 08, 202

Revised March 11, 2021

Accepted April 30, 2021

Available online May 25, 2021

Kata Kunci:

Pembelajaran Tematik,

Pendidikan Seni Musik

Keywords:

Thematic Learning, Music

Education

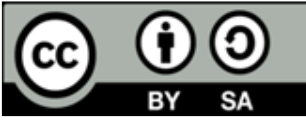

This is an open access article under the CC BY-SA license.

Copyright $(2) 2021$ by Author. Published by Universitas Pendidikan Ganesha.

\section{A B S T R A C T}

The industrial revolution 4.0 and 21st-century skills leave fundamental problems in the implementation of 2013 curriculum teaching materials with an integrated thematic approach, including learning the art of music in elementary schools. It is very important for teachers to integrate technology into learning. The purpose of this research is to develop interactive multimedia in the form of a digital songbook as a support for integrated thematic teaching materials. The type of research that has been used is Research \& Development which refers to the ADDIE. The subjects of this study were 4 (four) teachers and 100 elementary school students in the city of Padang. Data collection techniques and instruments were in the form of a questionnaire consisting of a validation questionnaire for validators and a practicality questionnaire given to teachers and students. The data analysis technique was obtained by taking the average results of product validation and practicality. The results showed that the average score of content and graphic validation was $84.1 \%$ in the appropriate category, while the average practicality score was $86.7 \%$. Thus, the Digital Song Book is feasible and practical to use in learning the art of music as a support for integrated thematic teaching materials in elementary schools that meaningful for elementary students. The findings of this study have significant implications for designers and teachers, as well as multimedia researchers.

\section{INTRODUCTION}

Indonesia is currently influenced by 2 (two) major trends which are marked by the rapid development of Science, Knowledge, Technology, and the Arts (IPTEKS). First, Industrial Revolution 4.0. Technology and digitization will revolutionize everything, making the overused and often ill-used adage (Schwab, 2016). Education 4.0 is a new paradigm in educational context in which it focuses on the innovation and maximizes the use of information, internet, and technology (Anggraeni, 2018) and second,

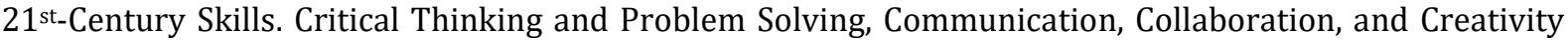
and Innovation (AACTE \& P21, 2010). Teachers play a significant role in helping students develop 21st 
century skills by applying methods that increase student's abilities (Alismail \& McGuire, 2015; Budiyono, 2020; Sari \& Priatna, 2020). The Industrial Revolution 4.0 and 21st Century Skills have an impact on the implementation of the 2013 curriculum in Elementary Schools (SD), which must integrate integrated thematic learning with the use of technology. This condition also has an impact on the way teachers teach students. Today, participation in the digital culture depends on the ability to interact in virtual groups of friends and groups of interest, where young people are capable of using applications fluently and on a daily basis (Alaloul et al., 2020; Ananiadou \& Claro, 2009), and advances in computing technology in today's digital age have reignited educators' interest in multimedia forms of communication because ofthe ease with which it is now possible to render illustrations, photos, animation, and video and incorpo- rate them with audio and text (Mayer, 2019).

The implementation of the 2013 Curriculum at the elementary level is carried out through an integrated thematic approach which is characterized by the incorporation of several subject matter content into themes or subthemes (Desyandri \& Maulani, 2019), and implementation of the 2013 curriculum aims to improve the quality of education in Indonesia, including the quality of primary school education (Mansurdin et al., 2019). One of the contents of the subject matter in the 2013 curriculum is Arts, Culture, and Crafts (SBdP) which is taught to be integrated with other subject matter content. The content of SBdP lessons is further divided into Fine Arts, Music Arts, Dance and Drama Arts, and Crafts. This article is focused on developing music learning or learning to sing. Musical art learning is given through the approach: "learning by singing, learning through singing, and learning about singing" (Ardipal, 2015; Desyandri, 2012). Singing has a role in the formation of a harmonious personality of students by paying attention to the level of development of students in achieving intelligence, including: musical intelligence, creative intelligence, and emotional intelligence. Singing is learning to provide opportunities to develop a sense of beauty in students by experiencing and experiencing the sounds of the singing expression itself. This sense of aesthetic gives students awareness that singing is a part of life. Singing can develop students' sensitivity to the environment, and students can appreciate and enjoy songs not only according to their intellectual tastes but also through their artistic tastes. Therefore, the process of learning to sing in elementary school (SD) is not giving stories or lectures, but rather through appreciation activities and expressing songs (Desyandri, 2012). Music can be important in establishing identity in a group, and it is also important in the formation of self-identity (Johnson \& Heiderscheit, 2018). Music is at the center of what it means to be human - it is the sounds of human bodies and minds moving in creative, story-making ways (Malloch \& Trevarthen, 2018).

Problems in the field show that the implementation of music learning, such as singing in elementary schools is not optimal, this can be seen from the learning process carried out by teachers who focus on learning content on developing music knowledge and skills to students, so that students can only sing the song, without understanding the values contained in the song (Ardipal, 2015). Learning only serves as entertainment and enriches knowledge but lacks value, only memorizes songs, students are guided by teachers to sing certain songs (Desyandri et al., 2019), and Teachers only make the art of music as learning that is less meaningful in its implementation (Desyandri \& Maulani, 2019). In other words, learning the art of music is only used to motivate students when they are bored after following several other subject matter contents.

The ideal conditions regarding technological progress, 21st-century skills, and problems that occur in the field show a wide gap. Education and learning in elementary schools, especially learning the art of music has not developed in accordance with the times that integrate technology with teaching materials. The same condition is also seen in the findings of previous studies. Several studies have carried out the development of multimedia/digital songbooks, but the results are still not optimal. In addition, teachers only use thematic teaching materials with minimal standards. The music teaching materials contained in it have not been fully described and have not been equipped with music teaching techniques with their own characteristics. Moreover, music learning has not accommodated the use of technology in the form of interactive multimedia. Based on the problems mentioned above, it shows the importance of harmonizing music learning which refers to the industrial revolution 4.0 and developing 21st century skills. The process of adapting and integrating learning with technological developments and $21^{\text {st }}$-century learning, the teacher must actively seek ways to leverage technology to foster these collaborations and methods of connecting with our students and the learning community (Poth, 2019), the development of information technology has influenced the use of various types of media as a learning tool (Miaz et al., 2018), and the digital media have extended their reach into the mundane heart of everyday life, most visibly with cell phones-gadgets now vital to conduct business affairs in remote areas of the world, as well as in bustling global cities (Coleman, 2010). So, the teachers need digital media to realize meaningful learning for students. 
Several previous studies related to the integration of technology and multimedia in learning the art of music in elementary schools, including: (1) The use of technology in thematic music learning in elementary schools has a lot of positive effects, including measuring music competence, supporting learning, and using multimedia (Ardipal, 2020), making the CodeIgniter application has proven to be very practical and effective for learning for elementary students (Fauziyah et al., 2017), (3) in the integrative thematic learning, the utilize the learning media that lead the students to actively, create the pleasant learning atmosphere, increase the student's learning interest and achievement (Primamukti \& Farozin, 2018), and (4) learning using interactive computer-based interactive applications more effectively in comparison with conventional media (Rachmadtullah et al., 2019). The findings of this study above are very different with this research. The findings of previous research are only a literature review and the applications that are made only to memorize lyrics and song notations, while the development research that has been carried out is complete. So, the novelty lies in adding elements of scales, musical accompaniment (minus one) as a means of singing practice, and the values contained in songs as a means of building student character. So that the development of this digital songbook can create innovative and meaningful learning, and can build the character of elementary school students. Based on this novelty, it was formulated that the purpose of this development research was to develop a digital songbook as a support for music teaching materials that were innovative, meaningful, and could be used as a means of building the character of elementary school students. The development of teaching materials is very important to do to get more optimal multimedia and as a way out in the process of optimizing music/singing art learning in elementary schools and producing digital songbook products, so the purpose of this development research is to produce a valid and practical digital songbook as a support integrated thematic teaching materials in elementary schools.

\section{METHOD}

The research method that has been used is research and development (R\&D) aimed at producing digital songbook products as a support for the implementation of thematic learning in elementary schools. The development design that has been used refers to the ADDIE development model, which consists of 5 stages: 1) Analysis, 2) design, 3) development, 4) implementation, and 5) evaluation (Molenda, 2015). The subjects in this study were 4 (four) classroom teachers and 100 students from 4 (four) elementary schools in Padang City. This development research is focused on the aspects of validity and practicality of using the Digital Songbook as a support for integrated thematic teaching materials for teachers and students. Research data collection consists of: (1) field studies. Field study data obtained through observations related to the basic problems, concepts, and characteristics of students. The instruments used are observation and questionnaires. Research data collection consists of: (1) field studies. Field study data were obtained through observations and questionnaires related to the condition of multimedia used in elementary schools, the need for digital media, students' preferences for multimedia, and the availability of supporting facilities for the implementation of digital songbooks in elementary schools, (2) the data collected was related to the concept of learning was analyzed using curriculum analysis sheets, (3) the collected data related to the needs and characteristics of students were analyzed and used as guidelines in designing digital songbook products.

Considering that this development research is focused on the aspects of validity and practicality of using the Digital Songbook as a support for integrated thematic teaching materials for teachers and students, the data collection was also focused on: validity data obtained by asking the validator's consideration using a validation questionnaire. The validators consisted of four experts, two material/music experts, and two media experts, while the practicality of data collection was obtained by asking teachers and students to fill out a questionnaire related to the likes, interests, and convenience of teachers and students in implementing digital songbooks. Ease of displaying aspects of product evaluation/digital songbooks at the same time. The data analysis technique was carried out by finding the average validation results regarding content, graphics, and language. Meanwhile, the practical data analysis technique was obtained by taking the average practicality results for the implementation of digital songbooks by teachers and students.

\section{RESULT AND DISCUSSION}

\section{Result}

The planning stage is based on the results of field observations on the analysis of the need for using Digital Songbooks for singing in elementary schools. Product specifications/digital songbooks are made using the main Adobe Flash CS6 application and are supported by several other applications, such 
as: Adobe Photoshop CS6, Sibelius 7, Format Factory, Neundo 2, and Adobe Air. Digital Songbook Content consists of; Song lyrics, musical notation, scales, sounds, videos, singing practice using minus one or musical accompaniment, pictures, and values contained in the song. Teaching materials that have been used need to be developed so that teachers and students look easier to use them. Digital songbooks as supporting teaching materials are arranged by taking into account the characteristics of students, namely: digital-based, equipped with notation, pictures, and musical accompaniment.

This digital songbook contains several songs that fit the theme of learning about ecosystem components and are close to the daily lives of elementary school students. The song consists of two Indonesian children's songs (the songs Kelinciku created by Mr. Dal and Kupu-kupu created by Mrs. Sud) using a major scale, one national anthem (Syukur created by H. Mutahar), and two folk songs from West Sumatra (the songs of Minangkabau created by No Name (NN) and Kampuang nan Jauah di Mato created by Aminos). This digital songbook is equipped with musical notation, lyrics, sounds, and pictures that follow the characteristics of the psychological development of elementary school students. The materials and content provided are tailored to the needs of students and related to age development and emotional maturity, as well as providing a balance between intellectual intelligence and other intelligences, such as intellectual, emotional, and spiritual intelligence.

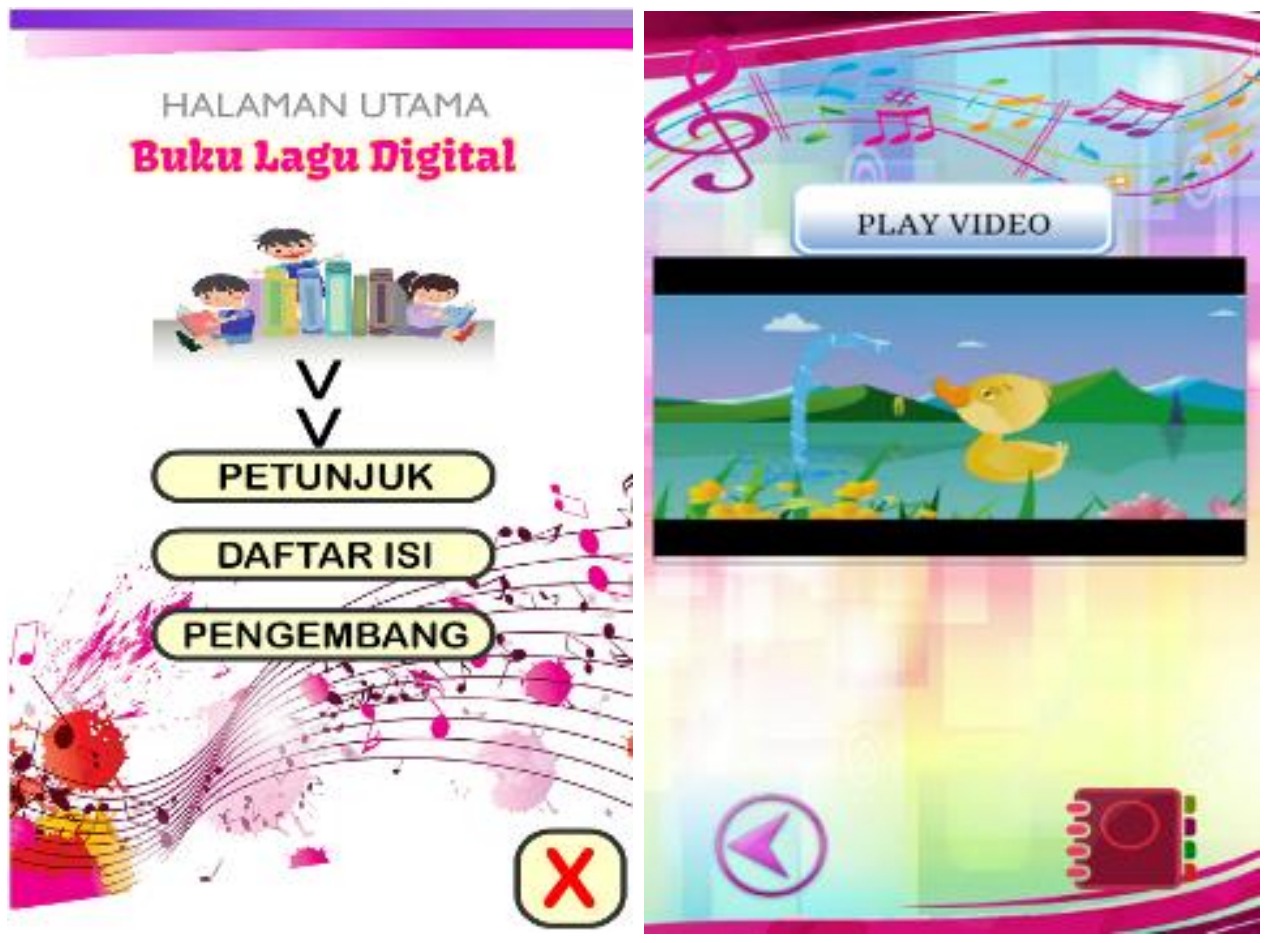

Figure 1. Digital Songbook Display

The development of a meaningful singing learning in elementary schools relies on analyzing the needs, concepts, and characteristics of students combined with the characteristics of student's music learning. So that it helps students in terms of attitudes, knowledge, and singing skills, and provides an experience of appreciation, expression, creativity, harmonization, and aesthetics that accommodates technological developments like a digital songbook. The results of the needs analysis of digital songbooks can be seen in Table 1 .

Table 1. The Results of Needs Analysis

\begin{tabular}{|c|c|c|c|c|c|c|c|c|}
\hline \multirow{2}{*}{ Questions } & \multicolumn{4}{|c|}{ Teachers } & \multicolumn{4}{|c|}{ Student's } \\
\hline & Yes & $\%$ & No & $\%$ & Yes & $\%$ & No & $\%$ \\
\hline Do you like learning to sing using interactive mutimedia? & 4 & 100 & & & 86 & 86 & 14 & 14 \\
\hline Do you like it, if learning to sing uses an IT-based book? & 4 & 100 & & & 85 & 85 & 15 & 15 \\
\hline $\begin{array}{l}\text { Do you like songbooks that are equipped with music and } \\
\text { songs liric? }\end{array}$ & 3 & 75 & 1 & 25 & 83 & 83 & 17 & 17 \\
\hline
\end{tabular}




\begin{tabular}{|c|c|c|c|c|c|c|c|c|}
\hline \multirow{2}{*}{ Questions } & \multicolumn{4}{|c|}{ Teachers } & \multicolumn{4}{|c|}{ Student's } \\
\hline & Yes & $\%$ & No & $\%$ & Yes & $\%$ & No & $\%$ \\
\hline Do you like it, if learning to sing using a digital songbook? & 4 & 100 & & & 87 & 87 & 13 & 13 \\
\hline $\begin{array}{l}\text { Do you like songbooks that are equipped with music } \\
\text { notation? }\end{array}$ & 4 & 100 & & & 86 & 86 & 14 & 14 \\
\hline Do you like songbooks that are equipped with pictures? & 4 & 100 & & & 90 & 90 & 10 & 10 \\
\hline $\begin{array}{l}\text { Do you like songbooks that are equipped with minus one } \\
\text { or musical accompaniment? }\end{array}$ & 4 & 100 & & & 82 & 82 & 18 & 18 \\
\hline Total & 27 & & 1 & & 599 & & 101 & \\
\hline Percentage & & 96 & & 14 & & 86 & & 14 \\
\hline
\end{tabular}

Based on the questionnaire data that has been given to teachers and students, it can be seen: (1) teachers and students need music learning materials that are equipped with integrated teaching materials with the used of technology in the form of digital songbooks, (2) the characteristics of students prefer music teaching materials that are equipped with lyrics, notation, musical accompaniment, and an attractive display. Concept analysis refers to integrated thematic learning with the theme of ecosystems, sub-themes of ecosystem components, learning 2. In learning 2, the content of Indonesian language, SBdP, and Natural Science subjects is captured. The basic competencies (KD) that will be achieved in SBdP learning are Understanding Scales (Knowledge Competence) and Singing songs with various scales with musical accompaniment. This KD needs to be mapped as an indicator of competency achievement, to get it a curriculum analysis is carried out as listed in the Table 2.

Table 2. Concept Analysis

\begin{tabular}{ll}
\hline \multicolumn{1}{c}{ Basic Competencies } & $\begin{array}{c}\text { Results of Analysis of Competency Achievement } \\
\text { Indicators }\end{array}$ \\
\hline $\begin{array}{l}\text { Knowledge Competence } \\
\text { Understanding Scales }\end{array}$ & $\begin{array}{l}\text { 1. Identify the characteristics of the scales } \\
\text { 2. Setting the scale }\end{array}$ \\
$\begin{array}{l}\text { Skill Competence } \\
\text { Singing songs with various scales with musical } \\
\text { accompaniment. }\end{array}$ & $\begin{array}{l}\text { Sing songs with major and minor scales using } \\
\text { musical accompaniment }\end{array}$ \\
\hline
\end{tabular}

The learning concept is based on curriculum development and teaching materials. The results of the analysis of the concept of learning the art of music presented in the table above are used as content in the digital songbook. The validity of product developed by validation involves 4 Validators, 2 content/music experts, and 2 media validators. Validation of data is obtained by giving the scoring sheet to validators who try to use digital songbook through handphone accompanied by a developer, so material validator can directly ask for things related to developed product and can directly give input in the form of criticism and suggestion to the developer which later will be used as a guide to revising the developed product. see in Tables 3 and Table 4 .

Table 3. The Validity of Content/Music Results

\begin{tabular}{|c|c|c|c|c|c|}
\hline \multirow{2}{*}{ Aspect } & \multirow{2}{*}{ Variable Criteria } & \multirow{2}{*}{$\begin{array}{c}\text { Item } \\
\text { Question }\end{array}$} & \multicolumn{2}{|c|}{ Assessment } & \multirow[t]{2}{*}{ Amount } \\
\hline & & & V1 & V2 & \\
\hline \multirow[t]{7}{*}{ Content } & 1. Conformity with Concept & 1 & 4 & 4 & 8 \\
\hline & & 2 & 4 & 3 & 7 \\
\hline & 2. Depth Content & 3 & 5 & 4 & 9 \\
\hline & & 4 & 5 & 5 & 10 \\
\hline & 3. Language & 5 & 5 & 5 & 10 \\
\hline & & 6 & 4 & 5 & 9 \\
\hline & & 7 & 4 & 3 & 7 \\
\hline \multicolumn{3}{|c|}{ Total } & 31 & 29 & 60 \\
\hline \multicolumn{3}{|c|}{ Validation Value } & \multicolumn{3}{|c|}{$85,7 \%$} \\
\hline
\end{tabular}

Based on table 3 above, it is known that the digital songbook that has been revised by the validator related to the conformity of the concept to the curriculum, the depth of the concept of the art of music, and the linguistic aspect developed is already valid with a percentage of $85.7 \%$ This means that 
digital songbooks can be used in learning the art of music. The media validator then examines aspects of the media present in the variables that have been designed by assigning value to the design feasibility assessment sheets, procedures, additional features, navigation, and media carrying capacity. Validators provide revision notes and assessment of the questionnaire in some recommendations, such as: unfit for use, feasible to use with heavy revisions, are eligible for use with minor revisions, and are worthy of use. The results of the digital songbook graphic validation can be seen in Table 4 .

Table 4. The graphic validity results of Digital Student Songbook

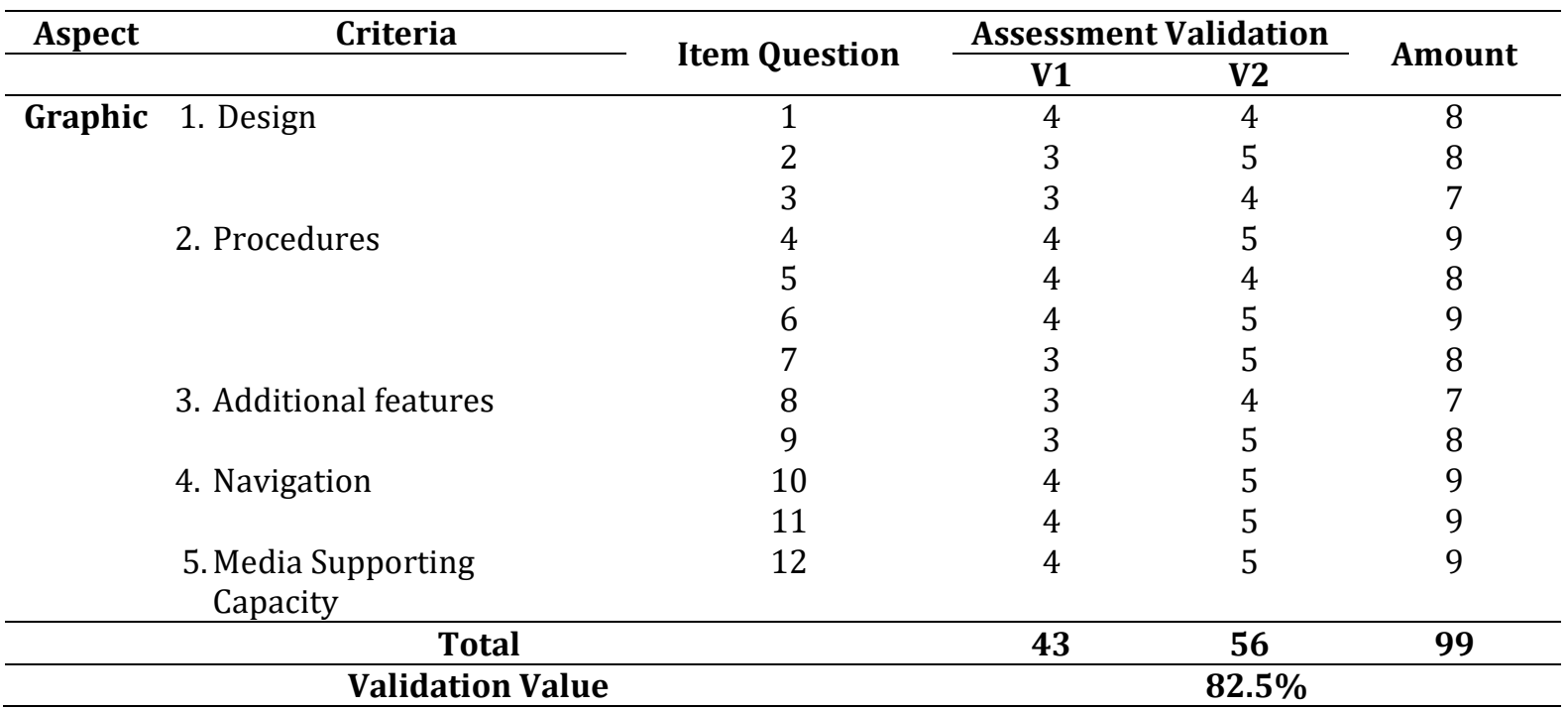

Based on Table 4, it can be seen that the digital songbook that has been developed has a graphical validity percentage of $82.5 \%$. This means that adobe flash CS6-based digital songbook is in the good category. After the validation process related to content, graphics, and language, the implementation of the development of a digital songbook was carried out as a support for integrated thematic learning for 5 th grade elementary school students. Based on tables 3 and 4 above, it is stated that the validation assessment obtained from the average content and graphic validation score are $85.7 \%+82.5 \%=84.1 \%$. Thus, the validity of digital songbooks can be categorized as feasible and can be tested in learning the art of music in elementary schools. A limited trial was conducted to determine the practicality of using media involving 4 (four) elementary schools in the city of Padang. Prior to the limited test, the digital songbook application was transferred to the teacher's and student's cellphones via the share-it application. After the app is shared, teachers and students practice using it outside of class hours. When teachers and students are able to run the application, only a limited trial is carried out. The results of a limited trial covering aspects of appearance, presentation of material, usefulness, and practicality obtained a percentage of $86.7 \%$, as shown in Figure 2.

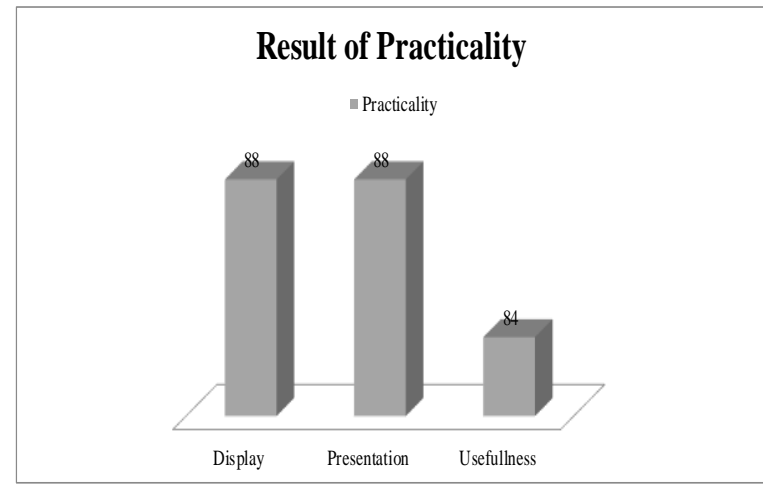

Figure 2. Result of Practicality

This means that the limited trials conducted on the development of digital songbooks based on Adobe Flash CS6 are in the Practical category. The evaluation process in research on the development of music learning using digital songbooks as a support for integrated thematic teaching materials in Grade $\mathrm{V}$ 
of Elementary School still needs improvement. The improvement was obtained from suggestions submitted by validators, teachers, and students. Further/final improvements in the form of: (1) deepening the concept of learning the art of music, so that it provides more meaning in the learning process, (2) adding a list of songs as an effort to disseminate subject matter for other themes/subthemes, (3) adjusting icons which is used with the characteristics of fifth grade elementary school students, and (4) beautifies the initial appearance of the digital songbook, so that students are more motivated and interested in studying diligently. This digital songbook contains several songs that fit the learning theme and are close to the daily lives of elementary school students. The songs consist of two Indonesian children's songs (Kelinciku and Kupu-kupu yang Malang song) that used major scales, one national song (Syukur), and two West Sumatra regional songs (Minangkabau and Kampuang nan Jauah di Mato song). This digital songbook is equipped with music notation, lyrics, sound, and images that are following the characteristics of the development of elementary school student psychology. Materials and content provided tailored to the needs of students and related to the development of age and emotional maturity, and provide a balance of intellectual intelligence with the intelligence it has, including a balance between intellectual, emotional, and spiritual intelligence.

\section{Discussion}

Based on the results of development research on music art learning that is integrated with the use of multimedia technology in the form of digital songbooks as a support for integrated thematic learning that has been described previously, it was found that the Digital Songbook is in: (1) the valid category. This means, to develop learning tools, validation is needed by several experts, so that the development can produce teaching materials according to the needs, concepts, and characteristics of elementary school students. This finding is also supported by several studies related to the development of teaching materials. To achieve maximum learning outcomes, learners should know about the management of learning media both as a teaching tool and as a support for the material/content of the lesson more clearly and easily can be mastered by students (Fauzan \& Arifin, 2019; Marjoni \& Indrapraja, 2016; Widyaningsih et al., 2020) and used a digital media developed on the topic of learning are declared valid and suitable for use in student learning (Kadek et al., 2021; Sriadhi et al., 2020). In addition, teachers and students are familiar with the use of mobile phones as interactive learning media and are highly favored by students. This is in line with research findings which state that the use of smartphones in Indonesia continues to increase every year, reaching the fifth-largest rank in the world and its users are dominated by children, young people, and people engaged in the world of commerce, and offices. Many applications exist on smartphones already a part of human life. Combining smartphone technology in learning can be done to solve various problems of students in learning and knowing the song is easy and fun (Elfiona et al., 2019; Gikas \& Grant, 2013; Purnomo et al., 2016) and the interactive media developed meets the standards of feasibility, practicality, and effectiveness for use in grade IV SD students (Lieung et al., 2021). The findings of this development research are also in line with the findings of Dilfa's research which developed a digital songbook for children/kindergarten students which stated that the digital songbook-based singing media can used to be a tool in the singing process in Kindergarten (Dilfa et al., n.d.), (2) the practice category. This means, that the used of multimedia or digital songbooks greatly supports the process of implementing innovative and meaningful learning for elementary school students. This is in line with the findings of other studies which state that the mastery of the concept of understanding of integrative thematic learning materials using interactive computer-based multimedia is higher than the students taught conventional media (Rachmadtullah et al., 2019), and the application of multimedia in primary school teaching has greatly mobilized the enthusiasm and initiative of student's learning (Gao, 2020) and multimedia learning modules were suitable for use in learning activities (Nursuhud et al., 2019).

In other hand, the benefits of this digital songbook, as well as singing media, also educate students to instill positive values both educational values and their own cultural values. These values serve as guidelines in giving birth to actions and behaviors that reflect the character of the Minang people, Minang songs contain local wisdom values that are very important and useful as guidance, advice, and educating students to behave according to Minangkabau customary norms, and can be used as a means of cultural literacy for students in elementary school (Desyandri, 2018). This view is in line with research findings which state that the use of learning media is intended to assist educators in delivering material and also to help students (Muchlis \& Putra, 2017). Thus it can be said that the use of interactive media and or digital songbooks greatly facilitates and helps teachers in learning to sing, so that students can sing well in accordance with the provisions of the art of music, innovative and meaningful learning for students, and can also be used as a means to build character. students. For this reason, it is highly recommended that teachers and students use multimedia development of digital songbooks in learning the art of music as supporting thematic teaching materials in elementary schools. This study has limitations in terms of 
effectiveness testing and a small number of participants. This can be the basis for developing a multimedia/digital songbook for other researchers to obtain more optimal findings

\section{CONCLUSION}

This research concludes that: (1) planning stage is done by taking into account aspects of student needs and characteristics, initial product development, product validation from media validator, and material validator, revision, and end products; (2) the result of validity test as a whole is a valid category and feasible to be tested; (3) practicality test result consisting of practical aspect with display criterion variable, presentation of material, and usefulness in terms of teacher and students. Thus, the Digital Songbook for singing lessons in elementary schools as a support for thematic teaching materials is very feasible and practical to use. This development makes them more motivated, enthusiastic, getting meaningful learning which will ultimately lead to an improvement in attitudes, increasing students' understanding and skills towards learning. Especially for music learning, the use of multimedia-based technology can be a supporting medium to improve musical skills so that student personality development can be realized.

\section{REFERENCES}

AACTE \& P21. (2010). Teachers for the 21st Century. In AACTE \& P21 (Issue September). https://doi.org/10.1787/9789264193864-en.

Alaloul, W. S., Liew, M. S., Zawawi, N. A. W. A., \& Kennedy, I. B. (2020). Industrial Revolution 4.0 in the construction industry: Challenges and opportunities for stakeholders. Ain Shams Engineering Journal, 11(1), 225-230. https://doi.org/10.1016/j.asej.2019.08.010.

Alismail, H. A., \& McGuire, P. (2015). 21 St Century Standards and Curriculum: Current Research and Practice. Journal of Education and Practice, 6(6), 150-155.

Ananiadou, K., \& Claro, M. (2009). 21st century skills and competences for new millennium learners in OECD countries. In OECD Education Working Papers (Issue 41). https://doi.org/10.1787/218525261154.

Anggraeni, C. W. (2018). Promoting Education 4 . 0 in English for Survival Class : What are the Challenges ? METATHESIS Journal of English Language, Literature, and Teaching, 2(1), 12-24. https://doi.org/10.31002/metathesis.v1i2.676.

Ardipal. (2015). Kembalikan Lagu Anak-anak Indonesia: Sebuah Analisis Struktur Musik. Panggung, 25(4), 343-355.

Ardipal. (2020). Pemanfaatan Perangkat Teknologi Dalam Pembelajaran Musik Berbasis. Musikolastika: Jurnal Pertunjukan Dan Pendidikan Musik, 2(2), 77-84.

Budiyono. (2020). Inovasi Pemanfaatan Teknologi Sebagai Media Pembelajaran di Era Revolusi 4.0 Budiyono. Jurnal Kependidikan, 6(2), 300-309. https://doi.org/10.33394/jk.v6i2.2475.

Coleman, E. G. (2010). Ethnographic Approaches to Digital Media. Annual Review of Anthropology, 39(1), 487-505. https://doi.org/10.1146/annurev.anthro.012809.104945.

Desyandri. (2012). The Usage of CTL Approach to Improve the Process and Learning of Singing to Studen Class III Elementary School. Jurnal Pedagogi FIP UNP.

Desyandri. (2018). Nilai-nilai Kearifan Lokal untuk Menumbuhkembangkan Literasi Budaya di Sekolah Dasar. Sekolah Dasar: Kajian Teori Dan Praktik Pendidikan, 27(1), 1-9. http://dx.doi.org/10.17977/um009v27i12018p001.

Desyandri, Mansurdin, Taufina, Arwin, \& Tamara, Y. M. C. (2019). Analysis of the Mastery of the Nusantara Songs in 4th Grade Elementary School Students. Proceedings of the 5th International Conference on Education and Technology (ICET 2019), 382(Icet), 482-485. https://doi.org/10.2991/icet19.2019.122.

Desyandri, \& Maulani, P. (2019). Penerapan Model Project Based Learning untuk Meningkatkan Hasil Belajar Seni Musik Pada Pembelajaran Tematik Terpadu di Sekolah Dasar. Jurnal Inovasi Pendidikan Dan Pembelajaran Sekolah Dasar, 3(2), 58-67.

Dilfa, A. H., Maestro, E., \& Putra, I. E. D. (n.d.). Buku Lagu Digital Anak Indonesia Ceria untuk Taman Kanakkanak: Studi Pengembangan Media Audio-Visual. E-Journal Sendratasik, 6(2), 9-15.

Elfiona, E., Zaim, M., \& Refnaldi. (2019). Mobile-Based Media as the Solution in Teaching and Learning Listening Skill. Journal of Physics: Conference Series, 1387(1). https://doi.org/10.1088/17426596/1387/1/012024.

Fauzan, F., \& Arifin, F. (2019). The Effectiveness of Google Classroom Media on the Students' Learning 
Outcomes of Madrasah Ibtidaiyah Teacher Education Department. Al Ibtida: Jurnal Pendidikan Guru MI, 6(2), 271. https://doi.org/10.24235/al.ibtida.snj.v6i2.5149.

Fauziyah, S., Tambunan, T. D., \& Telnoni, P. A. (2017). Aplikasi Belajar Bernyanyi dan Menghafal Lagu-lagu Daerah Untuk Siswa Sekolah Dasar Berbasis Website. E-Proceeding of Aplied Science, 3(3), 16541665.

Gao, X. (2020). New Mode of Distance Learning in Primary Schools in the Environment of Multimedia Computer Assisted Instruction. Journal of Physics: Conference Series, 1544(1). https://doi.org/10.1088/1742-6596/1544/1/012031.

Gikas, J., \& Grant, M. M. (2013). Mobile computing devices in higher education: Student perspectives on learning with cellphones, smartphones \& social media. Internet and Higher Education, 19, 18-26. https://doi.org/10.1016/j.iheduc.2013.06.002.

Johnson, K., \& Heiderscheit, A. (2018). A survey of music therapy methods on adolescent inpatient mental health units. Journal of Music Therapy, 55(4), 463-488. https://doi.org/10.1093/jmt/thy015.

Kadek, N., Riris, D., \& Wibawa, I. M. C. (2021). Socio-Cultural Diversity in The Form of Digital Comics for Fourth Grade Students : Validity and Feasibility. 5(1), 87-95.

Lieung, K. W., Rahayu, D. P., \& Yampap, U. (2021). Development of an Interactive E-book to Improve Student 's Problem Solving. 5(1), 8-15.

Malloch, S., \& Trevarthen, C. (2018). The human nature of music. Frontiers in Psychology, 9(OCT), 1-21. https://doi.org/10.3389/fpsyg.2018.01680.

Mansurdin, Helsa, Y., \& Desyandri. (2019). Primary School Teachers Problems in Implementation of Curriculum 2013. 5th International Conference on Education and Technology (ICET 2019), 382(Icet), 672-677. https://doi.org/10.2991/icet-19.2019.163.

Marjoni, I., \& Indrapraja, D. K. (2016). Penggunaan Media Musik Sebagai Aspek Pendukung Dalam Pembelajaran Seni Budaya Di Smp. Jurnal Pendidikan Dan Pembelajaran, 5(1), 1-19.

Mayer, R. E. (2019). How multimedia can improve learning and instruction. In The Cambridge Handbook of Cognition and Education (pp. 460-479). https://doi.org/10.1017/9781108235631.019.

Miaz, Y., Helsa, Y., Desyandri, \& Febrianto, R. (2018). Cartography in designing digital map using Adobe Flash CS6. Journal of Physics: Conference Series, 1088. https://doi.org/10.1088/17426596/1088/1/012069.

Muchlis, L. S., \& Putra, F. K. (2017). Development of Mobile Learning Based- Interactive Multimedia in Programming Language Class At Stain Batusangkar. Ta'dib, 20(2), 72-84. https://doi.org/10.31958/jt.v20i1.673.

Nursuhud, P. I., Oktavia, D. A., Kurniawan, M. A., Wilujeng, I., Jumadi, \& Kuswanto, H. (2019). Multimedia Learning Modules Development based on Android Assisted in Light Diffraction Concept. Journal of Physics: Conference Series, 1233(1). https://doi.org/10.1088/1742-6596/1233/1/012056.

Poth, R. D. (2019). Connecting Technology and Pedagogy. Journal of Digital Learning in Teacher Education, 35(3), 124-125. https://doi.org/10.1080/21532974.2019.1622916.

Primamukti, A. D., \& Farozin, M. (2018). Utilization of interactive multimedia to improve learning interest and learning achievement of child. Jurnal Prima Edukasia, 6(2), 111-117. https://doi.org/10.21831/jpe.v6i2.19183.

Purnomo, A., Hartono, R., Hartatik, \& Riasti, B. K. (2016). Pengembangan Aplikasi Info Lagu Nusantara Berbasis Android Untuk Melestarikan Warisan Budaya Indonesia. Jurnal SIMETRIS, 7(2), 527-536.

Rachmadtullah, R., Zulela, M. S., \& Syarif Sumantri, M. (2019). Computer-based interactive multimedia: A study on the effectiveness of integrative thematic learning in elementary schools. Journal of Physics: Conference Series, 1175(1). https://doi.org/10.1088/1742-6596/1175/1/012028.

Sari, R. M. M., \& Priatna, N. (2020). Model-Model Pembelajaran di Era Revolusi Industri 4.0 (E-Learning, MLearning, AR-Learning dan VR-Learning). Jurnal Ilmiah Fakultas Keguruan Dan Ilmu Pendidikan, 6(1), 107-115. http://ejournal.unsub.ac.id/index.php/FKIP/article/view/699/591.

Schwab, K. (2016). The Fourth Industrial Revolution. World Economic Forum.

Sriadhi, Khaerudin, Wahyuningtyas, N., Darni, Zainul, R., Adri, M., Rusdinal, Nasrun, Rahmulyani, Nuranjani, Nurmaniah, Wedi, A., Surahman, E., Aisyah, E. N., Oktaviani, H. I., Sri Martini Meilanie, R., Purnamawati, S. N., Hapidin, Listyasari, W. D., ... Adnan, E. (2020). Development of Moodlebased Content Learning System in MKDK Student Development Subjects at LPTK in Indonesia. Journal of Physics: Conference Series, 1594(1). https://doi.org/10.1088/17426596/1594/1/012021.

Widyaningsih, S. W., Yusuf, I., Prasetyo, Z. K., \& Istiyono, E. (2020). Online Interactive Multimedia Oriented to HOTS through E-Learning on Physics Material about Electrical Circuit. JPI Ournal Pendidikan Indonesia), 9(1), 1. https://doi.org/10.23887/jpi-undiksha.v9i1.17667. 